University at Albany, State University of New York Scholars Archive

2000

\title{
Home as a Place of Exhibition and Performance: Mayan Household Transformations in Guatemala
}

Walter E. Little

University at Albany, State University of New York, wlittle@albany.edu

Follow this and additional works at: https://scholarsarchive.library.albany.edu/cas_anthro_scholar

Part of the Feminist, Gender, and Sexuality Studies Commons, Latin American Languages and Societies Commons, Latin American Studies Commons, Other Languages, Societies, and Cultures $\underline{\text { Commons, }} \underline{\text { Race, Ethnicity and Post-Colonial Studies Commons, and the Social and Cultural }}$ Anthropology Commons

\section{Recommended Citation}

Little, Walter E., "Home as a Place of Exhibition and Performance: Mayan Household Transformations in Guatemala" (2000). Anthropology Faculty Scholarship. 10.

https://scholarsarchive.library.albany.edu/cas_anthro_scholar/10 


\title{
HOME AS A PLACE OF EXHIBITION AND PERFORMANCE: MAYAN HOUSEHOLD TRANSFORMATIONS IN GUATEMALA ${ }^{1}$
}

\author{
Walter E. Little \\ University of Illinois at Urbana-Champaign
}

\begin{abstract}
Since the beginning of the twentieth century, the town of San Antonio Aguas Calientes, Guatemala, has been incorporated into transnational movements of people, commodities, and ideas through tourism, development, and religious evangelism. The Kaqchikel Mayas living there have long looked outward from their community as they embraced, ignored, or criticized these global flows. Contemporary Kaqchikel Mayas have incorporated these global flows into the organization and maintenance of their households, while giving them a local interpretation. Some families have made their homes a place to enact their culture through exhibitions and performances for tourists. Such performances are indicative of the strategies increasingly used by Kaqchikel women, where the private household/ domestic sphere becomes public and also part of the global. These enactments have changed the economic and social organization of the household in terms of gender relations. (Guatemala, Kaqchikel Mayas, performance, tourism, gender, transnationalism, globalization)
\end{abstract}

In a 1912 article promoting tourism to Guatemalans and foreigners, San Antonio Aguas Calientes is described as one of the towns "most frequently visited by tourists for its beautiful panoramas." With descriptions of clothing, occupations, and community traditions, it highlights women as an attraction by noting that when they are "on the street they use colorful and clean outfits." The article also calls attention to the economic links Antonecos have with Antigua and Guatemala City, where they go to buy thread for weaving and to sell produce and other items such as mats. The article encapsulates aspects of life in San Antonio Aguas Calientes which are still present; cultural and economic exchanges with tourists, economic ties outside the community, and the differences between indigenous people and Ladinos.

The links to the nation-state and to global economic and cultural phenomena are further strengthened when it is recognized that San Antonio was one of the first indigenous towns in Guatemala to be missionized by Protestants. Reportedly, a school was founded by U.S. missionaries in 1874 (Brown 1998:3). By 1909, the Central American Mission established a permanent clinic and nurse training program (Garrard-Burnett 1998:34), and in 1917, Cameron Townsend, the founder of the Summer Institute of Linguistics/Wycliffe Bible Translators, arrived in San Antonio, where over the next twelve years he translated the First Testament into Kaqchikel Maya (Stoll 1982:33; Garrard-Burnett 1998:53). Since the beginning of the twentieth century, tourism and missionary activity have intensified.

Much has been written regarding the relationship between tourism, craft production, and religion (e.g., Annis 1987; Ariel de Vidas 1995; Deitch 1989; Ehlers 1993; Garcia Canclini 1993; Nash 1993a; Stephen 1991; Tice 1995). Indeed, Kaqchikel women there are world-renowned weavers whose products are collected 
by American, European, and Japanese aficionados of indigenous clothing, but this article explores the use of households as sites for tourist performances. The focus on these public performances will also explain how in some households gender relations are changing.

A well-known tourist destination, San Antonio Aguas Calientes is a relatively prosperous town located near Antigua, Guatemala, with an indigenous population of 6,262 out of 6,740 people (Rodríguez Rouanet 1996:172). Additionally, San Antonio was one of the favored sites for development in the 1970s because for over 50 years farmers there had "a reputation for being technically progressive, literate, and willing to innovate" (Annis 1987:44). Although economic development projects are not as common in San Antonio as in the past, in part because it is considered to be relatively developed, educated Antonecos, as managers and caseworkers, are a common presence in various development agencies operating throughout Guatemala. And farmers have not ceased being innovative, as in the case of one who turned a chance meeting in Antigua with an English traveler into an opportunity to surf the Internet and gather information on making organic fertilizer with earthworms. He now produces more fertilizer than he can use on his own fields and sells the rest.

Tourism has grown to be a part of the lives of nearly every person in San Antonio. Antonecos keep themselves informed of world events by listening to the radio, reading the newspaper, and especially by watching television, which they say allows them to gain insight into the practices of other peoples and cultures and thereby to help them figure out tourists. Increasingly more of them have cable television, which they use to watch programs in English, French, and German, in order to learn new words and strengthen their school knowledge of those languages. They also use it to follow teams in the National Basketball Association and the latest goings-on in Hollywood. Some Antonecos have traveled frequently to the United States and to Europe to visit family, conduct business, and vacation.

These flows of people, media, ideas, and commodities in late-twentieth-century San Antonio Aguas Calientes are common aspects of life for many people in many places around the globe. They illustrate how people are part of and participants in what Appadurai (1996:49) characterizes as "global ethnoscapes" that deterritorialize geographic boundaries. He claims that the "loosening of the holds between people, wealth, and territories fundamentally alters the basis of cultural reproduction" (Appadurai 1996:49). That is, in the words of Kearney (1995:549), "globalization entails a shift from two-dimensional Euclidian space with its centers and peripheries and sharp boundaries, to a multidimensional global space with unbounded, often discontinuous and interpenetrating sub-spaces." In recent years, scholars have studied and commented on these various flows (of ideas, people, commodities, etc.), specifically Morley and Robins (1995) on global media, Castañeda (1996) on anthropological inquiry and tourism, MacCannell (1992) on tourists, and Garcia Canclini (1995, 1993), Nash (1993a), and Tice (1995) on crafts, to mention but a few. Like Nash (1993b) and Tice (1995), this article contributes to a better 
understanding of the ways in which indigenous people respond to global cultural, economic, and media flows.

\section{TOURISTIC PERFORMANCES}

Almost since the first tourists arrived in San Antonio, performance has been a part of the marketing of textiles produced there. Guidebooks and Internet sites frequently portray Antoneca women seated at their backstrap looms. As Annis (1987:13) observes, "The image of the San Antonio woman at the loom-clad in her huipil [handwoven blouse] of blue and red and orange and a dozen other colors-has become a national icon for use on tourism and export promotion brochures." Indeed, pictures of Antoneca women weaving, usually at home in the courtyard, often with a child nearby, commonly used in tourism literature and clearly linking women to household and weaving, are depictions of women performing. Such images purport inside, intimate looks at women's work and homes.

Most touristic images of Kaqchikel women, like early visits by tourists to San Antonio, assume a passive subject to be gazed on by the tourist. As far back in time as they can remember, residents of San Antonio have had tourists wandering through their town, looking into their houses and taking pictures in order to get a glimpse of their lives. Women in San Antonio, however, were not and are not oblivious to the tourists' gaze (e.g., Urry 1990). By accommodating tourists, letting them watch, and then offering them woven items for sale, women became part of a global economy of handicraft sales.

The first truly organized performances of indigenous household activities came during the dictatorship of Jorge Ubico (1931-1944) in the Fería de Agosto ${ }^{2}$ (also described as "the national fair "La Aurora" and the "Summer Fair") held in Guatemala City for most of Ubico's tenure as dictator. A Pueblo Indigena was part of several exhibits showcasing Guatemalan industries, development, and people. Over the years that the fair was held, the Pueblo Indigena was consistently described in the Guatemalan press as the exhibit drawing the largest attendance. Tourists from Guatemala, Europe, and the United States visited the Pueblo Indigena to see how Mayas lived. Wattle-and-daub houses, called ranchos, were constructed and the village was populated by Maya from various highland communities, where they enacted their lives before the gaze of those visiting the fair. Maya men, women, and children were told to weave, fabricate bricks, tiles, and soap, and to make fishnets, pottery, and candles. They played music, danced, demonstrated "ancient rituals," and lived in their ranchos for the duration of the fair. Women carried out their usual domestic tasks, cared for children, and wove. Antonecos were described as "skillful at certain weavings, such as güipiles (blouses), fajas (belts), and ceñidores (sashes).”

Without going into a more thorough description of Ubico's National Fair, it is significant to note that the household and women were prominently featured in the Pueblo Indígena. Thinking back to her childhood participation in the fair, one elderly woman explained that it provided an opportunity for women and children "to travel 
to Guatemala City and meet indígenas from all over Guatemala." It was also, she explained, when they realized the economic potential of weaving for the tourist market. Mayas, however, were ordered by Ubico to participate in the fair in order to stimulate international tourism and help forge a sense of Guatemalan national identity, not to provide expanded economic and social opportunities for them. In conjunction with the fair, trilingual (English, Spanish, and German) picture books were published with pictures of San Antonio women weaving at backstrap looms, seated on reed mats in front of ranchos (Rubio 1938). Although the fair is now long defunct, tourism packages from companies such as Clark Tours and Kim' Arrin attract foreign tourists by promising stops in indigenous villages and marketplaces.

Today in San Antonio the performance of household activities appears in a variety of guises. The most common is the típica tienda, where residents along the road entering the town set up little stores in the street-side room of their houses. These stores, noted by Annis (1987:19-21), tend to be a room where típica is offered for sale and a loom is set up for weaving. Típica refers to traditionally inspired handwoven clothing and other items fabricated by Maya weavers and sold to tourists. Weaving allows women to produce more inventory, alleviate the boredom of waiting for tourists, and provide tourists with a show. During the course of my fieldwork, tourists frequently explained that they were enticed into marketplace locales or San Antonio tiendas by the sight of indigenous women weaving.

The Pérez family, one of the families Annis (1987:148, n. 20) describes as having a "monopolistic grip on the local tourist industry," has made use of two other versions of touristic performance. They are currently the only family officially endorsed by INGUAT, the Guatemalan government's tourism office, and supported by all of the major tour companies operating in Guatemala. One type of performance is located in a private textile museum in Antigua, Guatemala, where weaving demonstrations are offered and mannequins dressed in traje (traditional clothing) are located in displays of household rooms. It is an in situ style of exhibit, in which household life and the importance of textiles in Maya life are interpreted through a combination of artifacts, constructed settings, and actors. According to KirshenblattGimblett (1998:19), in an in situ exhibit "the object is a part that stands in a contiguous relation to an absent whole that may or may not be re-created." Thus, carefully selected items, a mannequin dressed in a huipil and corte, a mano y metate next to a comal, and a few ears of maize, as in one of the exhibits, serve to represent and mimic San Antonio life. Similar displays show female mannequins taking care of children. In the courtyard of the colonial-style house, a group of women weave together, joke with tourists, and answer questions in a form of improvisational theater. The combination museum, retail store, and theater is presented as a type of neutral arena in which tourists can learn as much about Maya life as possible in the shortest amount of time without having to actually go to a Maya town or household.

The other type of performance given by the Pérez family is located at the entrance to San Antonio. It takes place in a combination store-restaurant where weaving demonstrations are given and local dishes are served. Here tourists watch 
brief weaving demonstrations and listen to explanations of weaving techniques and the uses of clothing. They are then invited to purchase and try traditional San Antonio cuisine, such as pepian; stewed chicken, smothered in a sauce made from peppers, tomatoes, and onions. The restaurant overlooks the town, offering one of the splendid panoramic views frequently mentioned by tour guides. As part of the performance in this locale, tourists are told of the dangers of San Antonio. It is populated with thieves, rabid dogs, and diseases because of its unsanitary conditions.

While these performative arenas are presented as neutral to tourists, Antonecos reported feeling combinations of jealousy, anger, and shame for the ways that the Pérez family has dominated the tourism market in the Antigua-San Antonio area. ${ }^{3}$ So infuriated by the Pérez family are many Antonecos that merely mentioning their name can yield scathing commentaries on how they "have stolen all the tourists for themselves," how they "make pacts and payoffs with INGUAT and tour guides," how they have preyed on the misfortunes of Antonecos by purchasing prized pieces of hand-woven clothing at low prices when families are strapped for cash, and how they are misinterpreting Catholic and Maya traditions. The Pérez family is Protestant, going back several generations. During the celebrations for the cofradia Dulce Nombre (Sweet Name of Mary) on January 20, 1998, some Antonecos constructed a procession float that satirized the Pérez family's tourism/textile sales business. A living diorama, depicting a touristic scene with a marimba and some men dressed as obese women holding up pieces of shabby textiles, was constructed in the back of a pickup truck, labeled "Hotel/Posado Alida." Following the float were other Antonecos dressed as tourists-wearing short pants and sunglasses and taking pictures of each other, the crowd, and the float. As the float passed through the streets, the crowd roared with laughter. For days following the procession Antonecos talked about how hilarious the float was and how the Pérez family should feel ashamed for blocking tourism business from others.

Working against the hegemony of the Pérez family, who had very successfully kept tourists to themselves, since the late 1980s some women in San Antonio have taken their performances out of their tiendas and into Antigua's marketplaces and Spanish-language schools, where they weave, tell stories, and answer questions about daily life. As crime has increased in Guatemala over the last ten years, schools have encouraged these performances, which allow students to see weaving demonstrations within their safe confines. A typical performance with a question-and-answer period lasts less than an hour. One of the women performing in Spanish schools explained that she was not making much money selling to tourists at the Tanque de la Union marketplace, so she offered to give free weaving demonstrations at the schools. Her vending locale neighbor also began giving periodic performances. According to one tourist, it was "the best thing I saw in Antigua. It gave me a chance to learn something about how Indian women live." The tourist ended up purchasing close to $\$ 100$ worth of merchandise. Some women have forged international connections and have given weaving demonstrations and descriptions of household life in the United States and Europe. 
It is important to note that the self-conscious performances by Antoneca women take a very different tone from those described by MacCannell $(1976,1992)$ as the often hostile interactions between "ex-primitive" and "postmoderns." These Kaqchikel women are neither hostile toward tourists nor reconstructing a collective identity for themselves or tourist consumers. They attempt to construct a slice of San Antonio life which seeks to capitalize on tourists' curiosity and money. As tourists tend not to be fools and are mildly skeptical, the transparent presentations of San Antonio life and identity are sometimes regarded as unauthentic. KirshenblattGimblett (1998:72-74) discusses the intricacies of "staging culture" where, when the performance becomes spectacle, authenticity is called into question. The issue facing producers is "to present rather than represent that life."

Presenting is a complex and difficult task for Kaqchikel women, because the presentation of their culture through performance runs the risk of becoming a show which is considered not quite authentic by tourists. ${ }^{4}$ The staged productions by the Pérez family and those women giving weaving demonstrations in Spanish-language schools, while usually interesting to the tourists with whom I spoke, were often considered to be solely for their benefit. In the words of one tourist, the performance is "not really the real thing, but it was good." All the women performers commented that it is not enough to act out their domestic chores and weave in front of a group of tourists. Commented one woman, "It bores me. It bores them." The better performers are constantly modifying their presentations to keep tourists interested and policing themselves to help ensure that tourists believe the presentation is authentic. The following section will look at one family's attempts to make their presentations interesting and genuine in appearance.

\section{TRANSFORMING HOUSEHOLD TO PERFORMANCE SPACE}

Twice a day Gloria López prepares her family's house for tourists and students. The tourists (independent travelers and those on guided tours) visiting the López home come primarily from the United States, Europe, Korea, and Japan. Although the students may come from these areas of the world, they tend to be mainly from the United States. They participate in language programs which stress an immersion method of learning. Gloria's parents (Cecilia and Aleandro, both in their seventies) cannot remember tourists not visiting San Antonio Aguas Calientes. In fact, the street-side rooms of most houses on the road leading to the plazuela (town center), including those around the Catholic Church and plazuela, have been transformed into típica tiendas, and a daily típica marketplace is located in the plazuela. Whereas these stores sell material goods, the Lópezes sell stories and daily life. Both tourists and students visit Gloria's home to get a glimpse of "Indian" life, in hopes of seeing what indigenous people do when tourists are not looking.

Despite the Pérez family's monopoly with INGUAT and the major tour companies, enough other tourists and Spanish students studying in Antigua make trips to San Antonio to make típica sales worthwhile for many families there. Competition 
is fierce among vendors, who are always trying to figure out new ways to attract customers. It is not enough to just set up a tienda on the main road and wait for tourists to show up, so vendors visit Spanish-language schools, travel agencies, restaurants, and hotels to distribute fliers and to invite tourists to visit San Antonio. Some vendors go as far as to guide tourists from Antigua to San Antonio. When these businesses become inundated with solicitations and the owners and managers begin turning vendors away, vendors conceive new strategies ${ }^{5}$ to improve their sales.

\section{CONCEPTION OF THE MAYA PERFORMANCE}

Since the mid-1980s, various women in the López family have been selling típica as street peddlers in Antigua and the ruins of the Capuchinas Convent. As they watched their sales decline between 1994 and 1996, they conceived of one of the more innovative strategies to attract customers. They announced that they were a weaving/vending co-operative, named themselves Cooperativa Ixel, and printed business cards, the back of which lists their services: showing exhibitions, selling traditional clothing for ceremonies and daily use, and selling typical food such as tortillas and pepian. Next, they planned a program for tourists, consisting of five parts: 1) welcome and traditional stories that include courting practices and gendered work activities common in "traditional" Maya households; 2) dressing the students in traje for various ceremonial occasions, such as cofradia rituals and marriage ceremonies, which they perform in mock enactments; 3 ) a weaving demonstration, where visitors are invited to try their hand at weaving; 4) tortilla-making and eating pepian; and 5) informal conversation and sales. Going only to Spanish-language schools to sell their idea, they pointed out that no one was obligated to purchase anything, but ten Quetzales (about US\$1.50) would be required to cover the cost of the meal. Most Spanish schools tended to mark up this price to 30 to 60 Quetzales $(\$ 5$ to $\$ 10)$, claiming that it was to cover transportation and fees for the teachers who accompanied the students.

The Lópezes established regular business relations with the Christian Spanish Academy, Amerispan, Spanish School San José, and the Central America Spanish Academy. Other schools and organizations included the Instituto Guatemalteco Americano from Guatemala City, a group from the U.S. embassy, the Oxlajuj Aj Kaqchikel class, and a women's association from the Japanese embassy. To get this business, the Lópezes used various strategies to convince potential clients to make the trip to San Antonio. First and foremost, they de-emphasized the economic relationship. They stressed that they were not a tienda but a real household. According to Gloria, they opened their home to let "guests see what a Maya family lives like and hear traditional stories."

Second, they promoted themselves as a co-operative. This decision came after years of experience selling típica on the streets of Antigua. Tourists frequently asked them if their products were made by a weaving co-operative. Although they are not officially recognized as a co-operative, Gloria and her older sister, Zoila, explained 
that tourists are more sympathetic to co-operatives. ${ }^{6}$ To make themselves more like a co-operative they spoke to other weavers in San Antonio, offering to sell their products on consignment and pass special orders back to them. Some profits are then donated to sponsor activities associated with the Catholic Church, purchase clothing and school supplies for needy children, and provide food for elderly or incapacitated persons.

Third, they explained that the performance/exhibition is participatory and social. Few foreigners and non-Maya Guatemalans have opportunities to socialize and participate in a Maya household. In part, this is because not many tourists and Spanish students have the time to meet and develop rapport with Mayas. There are many stories of failed encounters with tourists who did not like the food, the living conditions, or the degree to which the houses were sanitized. Hosts felt insulted by their tourist guests' behavior and were hesitant to invite other foreigners into their homes. The Lópezes, on the other hand, expect these behaviors and although they prefer that the tourist/guests eat the food that is prepared, they are not offended if they refuse.

Fourth, they offered to take their performance/exhibition to the school, if the students cannot visit San Antonio. The Instituto Guatemalteco Americano agreed to a performance at its Guatemala City school and was so favorably impressed that it now makes periodic trips to the López household. Over the two years that I worked with the Lópezes, this pattern of first presenting at a school and then having students from the school visit the López home repeated itself, in part because they explained to students, teachers, and school administrators that Maya life was more than stories and weaving demonstrations. Students had to be in their house, smell the tortillas on the comal (griddle), and hear the sounds of the town.

It is important to remember that despite some altruistic motives, Cooperativa Ixel was founded to help the López family compete with other Antoneco vendors and make money. By opening their home to tourists, categories such as global and local conflate. But this conflation is not simply a blending of cultures or a new hybrid form of household. As tourists visit the López household and the Lópezes themselves modify and adjust their performance, their household organization and attitudes in relation to gender roles change. At the same time they maintain distinctions between themselves and tourists in and out of performative contexts.

\section{PERFORMING MAYA LIFE}

On days when a group of tourists or students is expected to visit, the López family transforms the physical space of their home into a theater-in-the-round. This involves partitioning off the private areas of the home and removing electrical appliances and as many other signs of non-Maya material culture as possible. Aleandro and Cecilia, who purchased the land over 30 years ago, have since given two-thirds of the property to two of their sons. Their houses, located to either side of Aleandro and Cecilia's, are built of reinforced concrete with tile floors, and 
equipped with refrigerators and gas stoves, like other modern houses in San Antonio. Aleandro and Cecilia's house, on the other hand, is of an older style of construction, with cane walls and packed dirt floors. Although it has electricity, that is made inconspicuous to tourists/visitors.

One of the first orders of business is putting up partitions between the three households. This is done by stringing clothesline across the courtyard and hanging bolts of corte material (used for wrap-around skirts) and handwoven tablecloths on it. On some performance days Aleandro helps rig the line for partitions and moistens the dirt yard with water and sweeps it to keep the dust down. Then he goes to work in his fields. Cecilia, her daughters, Gloria and Zoila, their sister-in-law, Agripina, and Aleandro's younger sister, Bernarda, hang two backstrap looms and prepare a meal of pepian and tortillas, saving some of the masa (corn dough) so that their guests can learn to make tortillas. Sometimes Cecilia and Aleandro's grandchildren, both male and female, help with preparations, but most of the time they are attending school.

When the guests arrive, they pass through a fence made of cane, walk along a wall decorated with various pieces of típica, and into a small courtyard that is bounded on two opposing sides by walls of corte and típica and on the two other opposing sides by a kitchen and combination-use room which serves as a warehouse, religious altar, and formal meeting room. Both are made of cane. Off to the side of the courtyard is a large jocote tree, which Antonecos say produces San Antonio's typical/traditional fruit. The guests are surrounded by Maya material cultural: textiles are everywhere, bags of maize and beans from Aleandro's fields rest to the side of the general-purpose room, and the smell of tortillas, pepian, and pine fill the air. Cecilia, Gloria, Zoila, and Bernarda greet their guests dressed in their finest San Antonio-style, brocaded huipiles.

An artist, Fusco (1995:40), writes that "the construction of ethnic Otherness [is] essentially performative and located in the body." Her essay, which outlines the white European and American colonial practice of displaying Others, also describes her and Gomez-Peña's artistic experiment that satirizes these colonial practices of display and explains how "human exhibitions dramatize the colonial unconscious of American society” (Fusco 1995:47). ${ }^{7}$ According to Fusco (1995:46), "actual encounters [with the Other] could threaten the position and the supremacy of the appropriator unless boundaries and concomitant power relations remain in place." Like Fusco and Gomez-Peña, the López family is self-conscious about its performance. Whereas Fusco and Gomez-Peña construct a performance to expose "white people's" practices of making an Other, the Lópezes construct an equally sophisticated performance playing on tourists' practices, desires, and beliefs. Fusco and Gomez-Peña were interested in constructing and playing with boundaries which mark and separate whites from their Others in ways that cause reflection, anger, doubt, complicity, or some other reaction to make viewers think about their relation to the people in the cage. The Lópezes, too, are concerned with constructing boundaries, but they do not challenge tourists to doubt their beliefs or exposed unconscious desires projected to 
the body and artifacts of the Other. They try to use the interests, desires, and curiosities of tourists to draw them into the performance and to confirm their beliefs about the exotic, different Other. The tourists and students who visit want to see and experience something contrastive to themselves. If the Lópezes are too much like the tourists, the performance fails. Hence, attending to boundaries is fundamental to the success of the performance and subsequent sales of típica. In other words, the Lópezes must consciously make themselves different from tourists.

To ensure that difference is maintained, they speak to each other (usually stage instructions) in Kaqchikel Maya. Gloria and Zoila have the most verbal interaction with guests, with Gloria serving as the narrator who tells stories and describes San Antonio life. She tells her guests, "Please excuse my poor Spanish. If I speak slowly, it is because Spanish is my second language and it is difficult for me to find the correct words." She and her sister interpret for their mother, "who knows only a few words in Spanish." (It is important to note that all of them read and write in Spanish and that in most public and in some home activities, Spanish is the modus operandi.) Their brothers, who live in the houses to either side of the performance area, are kept out of the performance. One is employed at the Nestle fruit processing plant between San Antonio and Antigua, and the other is a skilled carpenter and talented sculptor involved in Maya political activism who likes to discuss why neither Marxism nor capitalism is for Antonecos. Furthermore, they explain that the success of their co-operative helps them maintain traditions such as weaving, maintaining the cofradias, and showing their children that Maya culture is aesthetically and economically valuable. They also used me like a stage prop. Most Antonecos know something about anthropology through direct contact with anthropologists who conducted or are conducting research in San Antonio, such as Annis $(1988,1987)$, Brown $(1998,1991)$, Wilhite (1977), and others. The Lópezes called the attention of the tourists to my presence, telling them that I was there to study the people of San Antonio because their traditions are unique and special. They engaged me in conversations with them in Kaqchikel and had me occasionally interpret for them because some things could "only be explained in Kaqchikel."

Their practices of making themselves different always ran the risk of derailing because of skeptical tourists. This was the case during one performance when a well-traveled woman in her fifties announced to her classmates in English, "I think the Lacondon Indians are the most authentic Mayas. They haven't changed as much as those here. They are not as commercial." Another student asked me if this was true. My vague reply that both groups were equally authentic led to a few of the students debating this for a few minutes. Eventually they decided, despite this woman's opinions, that the Lópezes were authentic Mayas, just different from the Lacondones.

The core of the López performance of Kaqchikel Maya life and household in San Antonio is the construction and maintenance of tradition. The traditions are what link them to place and past. ${ }^{8}$ In the world that the López women describe, male and female gender roles are clearly defined. Women weave, cook, and care for children. 
Men farm, manage the finances, take care of the saints, and deal with outsiders. Their guests, tourists or students, never questioned the contradiction before them, that they, as outsiders, were interacting with women, who were, according to Gloria, "timid of strangers." In the couple of dozen performances I watched, the Lópezes' guests always expressed their gratitude for being allowed into their home and permitted some time to see how "real Mayas" live. Even the skeptical tourist, mentioned earlier, told me how "surprised and fortunate" she was for having the opportunity to go into a "real home."

\section{HOUSEHOLD AS HOME}

The López house is a real home. When it is not transformed into a stage, it is where they live. Their other children's homes are never used as places of performance. Home and stage are one. The Lópezes are characters portraying Mayas, but they are also Mayas. Actually, they call themselves Mayas while performing for tourists and then Kaqchikeles and Indígenas in all other contexts of their life. This helps them maintain boundaries and distinguish between the life they show tourists and the life when they do not perform. This is not merely a semantic degree of difference simply because the performance is staged, stylized, and simplified. One of the problems that the Lópezes confront because of their house as home and stage is that they do not always live, or even want to live, in the ways that they portray themselves.

Bruner and Kirshenblatt-Gimblett (n.d.:68-71) explain how the Maasai and the Mayers face a similar problem because the Mayers' ranch is both home and stage for them. As with the Maasai, "it becomes essential to keep the boundaries straight, to distinguish between who is and who is not in the picture, and to know precisely when the picture begins and when it ends" (Bruner and Kirshenblatt-Gimblett n.d.:70). The previous section discussed the importance of the Lópezes constructing and maintaining boundaries for the benefit of the tourists who visit them. It is equally important to recognize that the boundaries help the Lópezes separate the house as home from the house as stage. It allows them to pursue their lives not as actors following a script anchored in and constrained by tradition. That life is often in contradiction to the life that is performed. While they perform without television sets and blenders, they make use of them when the house is not a stage. They are more preoccupied with their children and grandchild attending college than whether they strictly follow the traditions they describe.

At the same time, some traditional activities are not included in the household performances. Not once did the Lópezes discuss performing curing rituals, taking care of the saints, honoring the dead, or planting rituals. The meal that they consider most authentic, ichaj (a generic term in Kaqchikel for a variety of greens that are boiled or fried with egg batter and served with chile, onions, and tomatoes), is not served to tourists visiting their home. 
These distinctions allow Antoneco families, such as the Lópezes, to distinguish between the household as stage and the household as home, while also allowing them to mask from tourists the ways that they practice their lives and pursue interests that may not be considered traditionally Maya. However, since they began producing their performances and making money from them, certain changes have occurred in their household, particularly in terms of gender relations.

\section{HOUSEHOLD GENDER DYNAMICS}

In the cases of the López family, the Pérez family, and others mentioned briefly, the persons maintaining boundaries and defining who are Mayas, Kaqchikeles, and Indígenas are women. The performance of Maya life in contemporary San Antonio is a "gender-specific activity" (Nash 1993b). Nash's discussion of the ways Maya households have changed in light of the penetration of the world market in Amatenango, Mexico, has some parallels with San Antonio. In Amatenango, pottery production tended to be a gender-specific activity, which complemented men's semi-subsistence agricultural activities. It was and is a component of a woman's "identity as a wife and manager of a household" (Nash 1993b:133). Pottery sales were not viewed as the way for families to gain subsistence. However, as men migrated out of the community in search of work and tourism touched Amatenango, women increasingly began supporting themselves and their families from pottery sales, especially to tourists. This has changed the gendered relations of Amatenango life. In one case, a man helps his wife in producing pottery. As pottery prices and demand for pottery have risen, pottery production "can be used to subsidize agriculture" (1993b:135). It also has made it possible for women to support children without the aid of men, making them more economically independent and powerful within the community. According to Nash (1993b:139), "the changing value of women's contribution through the greater intensity of artisan production is affecting betrothal customs, marital relations, and the redistribution of wealth within the family."

As a result of tourism and strong típica sales, gender relations in San Antonio have changed too. The Pérez sisters, Alida and Carolina, are two of the wealthiest and powerful people in San Antonio because of their successes in the típica market. After Alcides López (not related to Aleandro and Cecilia) was killed by a death squad in 1979 (Annis 1988), his widow and daughters went from being a relatively poor farming family to relatively successful típica weavers and vendors. Their houses are filled with luxuries like cable television and stereos. In many San Antonio households, selling típica has provided women with an economically viable activity. In some cases, like those mention above, and in the case of the Lópezes' tourist performances combined with sales, women become the primary breadwinners, deciding how to use family finances and choosing when and whom to marry.

This is illustrated by the decline of one of the traditional practices by which a young man and his parents ask a young woman's parents for their daughter's hand 
in marriage. In the past, a man and his parents were responsible for providing a gift basket filled with fine textiles woven by female family members or purchased from a vendor, bottles of hard liquor, honey, bread, and chocolate to the mother of his betrothed. Called the k'utunik, it is not as widely practiced because it is harder for men to raise the money, and women say that it is not reasonable to require a man to provide such a gift when women make more money and want to decide whom they marry. In some cases, smaller, less expensive baskets are given to future mothers-inlaw because of their symbolic value.

By inviting tourists into the home, the Lópezes' household has changed in other ways not influenced by economics and local politics. This contact has led to changes related to gender roles, taste, and aesthetic sensibilities. Aleandro farms but has changed his routine to support the activities of the female members of his household. He helps with kitchen chores and watches children, freeing the women to visit potential clients. In many households women serve men meals and eat apart from them on reed mats. At the López house men and women eat together. Men are expected to help serve food and take away dishes at the end of the meal.

During the informal conversation and socializing portion of their performance, the Lópezes and their guests swap stories about cultural differences and pose for pictures. This has resulted in them exploring new types of food, experimenting with the ways they take pictures of themselves, and thinking about the ways men treat women. One of the more common comments by their visitors is how women and men's work can be so separate and women so subordinate to men. Ethnographic literature abounds for Mesoamerican cases where women are subordinate to men (e.g., Bossen 1984; Ehlers 1990; Nash 1993a; Stephen 1991). However, like many successful women in San Antonio, the López women run their households, control finances, and make decisions about how leisure time is spent and what leisure items are purchased. Interaction with tourists who make comments about gender inequalities has stimulated conversations about women's roles in Guatemala society and resulted in their reflection about appropriate sexual behavior and alcohol consumption. But for tourists they explain that while their work is different and separate from men, it is not subordinate. In fact, as Gloria tells them, "It helps us maintain order and avoid confusion. Men do what men do and women do what women do."

Not all households are as peaceful as the López household. In a few others, run by successful businesswomen, men have become abusive and turned to excessive drinking. Such behavior is not condoned by the community and San Antonio women have not been run out of town or killed for their successes, as was the president of the pottery co-operative in Amatenango (Nash 1993b). Women in San Antonio are recognized by community members as important contributors to the maintenance of the town, economically and culturally. In late December 1997, the plazuela vendors began developing a performance piece for tourists that showcased traditional women's work. During the trial run, the mayor and other city officials visited to show their 
solidarity with the women and pledged to help them attract tour companies and gain INGUAT approval.

The men I worked with in San Antonio frequently mentioned that women uphold traditions and cultural markers, such as language, clothing, and food; that Kaqchikel, Indígena, and Maya culture originates and is reproduced by women. While some men were jealous of women's economic successes and the prominent representation of women in INGUAT and international-tourism promotional materials, they were proud of the recognition that San Antonio women have received nationally and internationally. What men are somewhat reluctant to admit is that women are also bringing new ideas about how to run their households, guide economic, political, and religious committees, and participate in local, state, and global contexts.

\section{INGUAT AND THE PÉREZ FAMILY}

Making their household public has resulted in the Lópezes having some problems within their community and facing some obstacles with the Guatemalan government. One of the local problems related to the plazuela vendors' jealousy of their success. Plazuela vendors, the Lópezes, and other vendors and weavers felt a sense of camaraderie because they were getting roughly the same number of customers. Additionally, they were united against the Pérez family's hegemonic position in the textile/típica and tourism business. Although the Lópezes only attract a fraction of the tourism business going to the Pérez family, plazuela vendors commented that they must have cut underhanded deals and offer textiles at artificially low prices. The other local problem faced by the López family relates directly to the Pérez family. As Carolina and Alida watched small buses shuttle groups of ten to twenty tourists past their tiendas to the López household, sometimes as often as twice a day, five days per week, they decided to take measures to increase their hold on tourism in San Antonio. One strategy was approaching Spanish schools that took students to the López house. When that failed, they spoke with INGUAT, since they are the only family endorsed by the government tourism agency. Before waiting to see if INGUAT would shut down the Lópezes, they visited them and threatened them with violence. The Lópezes made the threat public knowledge and this helped them improve the strained relations they were having with other vendors, because threats from the Pérez family were commonly known. The Lópezes did not stop their performances and the Pérezes have not acted on their threat.

After Gloria was satisfied with the oral part of her performance, after her father and brothers made repairs on the buildings used in the performances and constructed a modern bathroom with a toilet and wash basin, and after the other women felt at ease with tourists and Spanish students who visited, they decided to court INGUAT. In other words, they decided to go big time and get some business from the biggest tour companies operating in Guatemala, such as Kim' Arrin Travel and Clark Tours. These companies and others, including STP Guatemala and Neys Viajes y Turismo, S.A., tend to patronize businesses that are endorsed by INGUAT. 
For a few months, they tried to make contact with INGUAT officials who were instrumental in giving INGUAT approval to tourism businesses. After visiting INGUAT's offices in Guatemala City several times and calling by telephone on numerous occasions, they learned that a contingent from INGUAT would come to watch their performance and inspect their house. The inspection came in late May 1998 and went without complications. The inspectors approved of the house, calling attention to how "traditional" it was with its cane walls and packed dirt floors. They liked the large religious altar adorned with candles, statues of saints, flowers, preColumbian pottery shards, and incense. The textiles exhibited received high marks and the performance was considered authentic and entertaining. The bathroom exceeded all their expectations. Gloria and Cecilia explained to me that they felt INGUAT approval was assured and that their household would be listed on INGUAT promotional materials and they would be recommended to the large tour companies. However, when the decision was made, they learned that they would not get INGUAT endorsement. The reason they were informed had nothing to do with their house or performance. It was according to one of the officials the "best portrayal of Indígena life" he had seen. The reason had to do with the town. The streets had to be cleaned and the town needed to be made more traditional. Only Spanish colonial-style buildings or cane-style buildings would be acceptable. More people in San Antonio had to wear traje and speak Kaqchikel. They suggested that the Lópezes talk to their neighbors and the mayor about making these changes. Aleandro commented to me that those changes are unreasonable and impractical. The López women pledged to continue working with Spanish schools, despite lack of endorsement from INGUAT, and went directly to Clark Tours to convince the company to take tourists to their home. When I left Guatemala in August 1998, they were still hopeful that they would reach an agreement with Clark Tours.

\section{CONCLUSIONS}

This article has described the ways in which the residents of San Antonio Aguas Calientes have made the performance of household activities an economic activity within global tourism flows. In the transformation of private space to public space, some San Antonio women have opened their homes to tourists, students, tour guides, anthropologists, and Guatemalan government officials. In particular, the López women have drawn on commonly known traditions to exhibit their house, present domestic activities, and tell stories about Maya life. This has placed their household into public spheres of debate from local to the international contexts, as townspeople, government officials, and tourists enter their household, consume their production, and comment on it.

As numerous chapters in Nash's (1993a) edited volume illustrate, Mesoamerican artisans, households, and towns have changed as a result of entering and/or being absorbed into late-capitalist systems of global economic flows. Antonecos are no exception. However, in the case of Nash's study (1993b) and in Ehlers's (1993) 
analysis, the households and towns of the producers have relatively little direct contact with tourists. In San Antonio, the town and its residents have been objects of tourism for nearly a century. The López family's production of their household as a performance space intensified interactions with tourists and led to changes in the management of the household, finances, and gender relations that did not occur when the women were merely street peddlers of típica.

The Lópezes' performance calls attention to the contradiction between the ways they perform their lives and the ways that they live their lives backstage. What they claim are transparent presentations of their lives increasingly become constructed traditions as they modify them in order to satisfy their tourist and student guests. At one time or another, members of the López family have commented on the strain of being "traditional." My apartment in Antigua became a place of refuge for the López women from other Antonecos and tourists (who sometimes spotted them in Antigua out of San Antonio traje), where they could watch television, joke, and eat my "gringo food."

The complications of performing and exhibiting to tourists have been discussed by Bruner and Kirshenblatt-Gimblett (1994), Castañeda (1996), Fusco (1995), Karp and Lavine (1991), Kirshenblatt-Gimblett (1998), MacCannell (1992), Mitchell (1991), and Picard (1995). Most have discussed tourism performances and exhibitions of ethnic Others within the contexts of United States and European colonial practices, in which anthropology has been used. Indeed, the question of who are Mayas and who are Indígenas is inextricably linked first to colonial and then later to anthropological and touristic discourses in which the developed West sees and makes its Others.

Unlike most cases studied by academics of Latin America, ${ }^{9}$ some Antonecos, such as the Pérez and the López families, are taking the exhibition and performance of Mayas (or Guatemalan Indígenas) into their own hands. Many, even those not connected with performance or típica sales to tourists, recognize, at the very least, that most tourists want to see the types of Mayas that guidebooks and brochures promise. What they find frustrating is being represented in touristic contexts where they have no control and/or access to potential economic benefits from these representations. They feel that it is their right to present and represent themselves in ways that are economically advantageous to them. The difference between this and the Western practice of exhibiting Others is that Antonecos decide who is exhibited, what is performed, and how performances are made. They then can control the money made from the exhibition/performances.

Bruner and Kirshenblatt-Gimblett (n.d.:71) comment that a "Maasai performance constructed for tourists becomes re-produced as the Maasai, and comes to stand not only for all Maasai but for African tribesmen, for the primitive." Certainly, there is a potential for Antonecos, especially since some are presenting the Maya household, whether in an actual house setting or at a school or other location, to be viewed as "the" Maya. But as they were quick to point out, the concept and person designated as Maya is already a public term. When I asked Antonecos if they were Mayas, they 
always corrected me, saying that they are the "descendants of Mayas." However, when it was time to sell típica and exhibit themselves and household activities they became Mayas.

It is the women in San Antonio who portray "Maya life." However, unlike the people of Amatlán, Mexico (Sandstrom 1991), where the household and the community are places where people can be themselves, be Indian, Antonecos cannot expect to find such refuge. The house becomes public space, where the women have to be self-conscious about how they portray themselves to outsiders. The irony of this is that the more they, especially the López women, perform "Maya life," the farther away from the traditions they present in their private lives.

\section{NOTES}

1. An earlier version of this article was presented at the 76th Annual Meeting of the Central States Anthropological Society, April 16, 1999. The current version has benefited from the comments of June Nash, Mahir Şaul, various participants at the Central States Annual Meeting, anonymous reviewers, and editorial suggestions from the editors of Ethnology. The research on which this essay is based was generously supported by grants from the U.S. Fulbright IIE, the Wenner-Gren Foundation for Anthropological Research, and FLAS Title IV.

2. The information here comes from newspaper accounts in Diario de Centro América between August 1932 and November 1936.

3. While studies of peasants and artisans have discussed envy at some length (e.g., Foster 1988), it is important to emphasize that Antonecos are careful to mask from tourists any jealousy they feel among themselves.

4. It is not my intent to measure Antoneca performances against an ethnographic original to gauge their authenticity, as MacCannell $(1992,1976)$ has done. Indeed, while authenticity is an issue for some tourists, it was not for the women presenting or for me. Bruner and Kirshenblatt-Gimblett (n.d.:27) contend that it "serves no useful purpose to denigrate tourist performances as inferior reproductions, but seems more reasonable to take such performances as topics worthy of serious scholarly inquiry." 5. Many vendors from San Antonio who sell in Antigua have agreements with businesses that cater to tourists. Sometimes it is a symbiotic relationship, where típica vendors are permitted to sell in hopes that their presence will attract tourists, who will then stay in the hotel or buy a meal. In other instances, the relationship is economic. The vendors pay the proprietor rent for the right to sell típica in his or her establishment. Vendors who have made these arrangements are very territorial and expect other vendors not to infringe on their space.

6. Annis (1987:45) explains that co-operatives may not have taken hold in San Antonio because Antonecos had easy access to many services typically offered through co-operatives, such as marketing, credit, supplies, and technical assistance. Antonecos, however, explained that co-operatives failed because families put themselves before the co-operative, individuals feuded too much over the ways the co-operative should be managed, the co-operative stifled the creativity of individual weavers and consequently led to inferior products, and (the most cited reason), the co-operative fell under the control of the Pérez family.

7. Fusco and Gomez-Peña's performance art piece involved placing themselves in a cage, dressed as fictitious, undiscovered Amerindians. Audiences were then invited to touch them, pose for pictures with them, and look at the males' genitals for an extra fee. They played with cultural boundaries by incorporating items such as boom boxes into the exhibition. The piece toured the United States and Europe during the quincentennial celebrations of Columbus's stumbling onto the Americas.

8. See Watanabe (1990) and Wilson (1995) for discussions about the ways that Mayas link identity and tradition to geographical space. 
9. Scholars working in other areas of the world have analyzed the ways that indigenous people represent themselves when dealing with tourists (e.g., Adams 1997, 1995; Errington and Gewertz 1989; MacCannell 1992).

\section{BIBLIOGRAPHY}

Adams, K. 1995. Making-Up the Toraja? The Appropriation of Tourism, Anthropology, and Museums for Politics in Upland Sulawesi, Indonesia. Ethnology 34:143-53.

1997. Ethnic Tourism and the Renegotiation of Tradition in Tana Toraja (Sulawesi, Indonesia). Ethnology 36:309-20.

Annis, S. 1987. God and Production in a Guatemalan Town. Austin.

1988. Story from a Peaceful Town: San Antonio Aguas Calientes. Harvest of Violence: The Maya Indians and the Guatemalan Crisis, ed. R. Carmack, pp. 155-73. Norman OK.

Appadurai, A. 1996. Modernity at Large: Cultural Dimensions of Globalization. Minneapolis.

Ariel de Vidas, A. 1995. Textiles, Memory and the Souvenir Industry in the Andes. International Tourism: Identity and Change, eds. M. Lanfant, J. Allcock, and E. Bruner, pp. 67-84. London.

Bossen, L. 1984. The Redivision of Labor: Women and Economic Choice in Four Guatemalan Communities. Albany.

Brown, R. M. 1991. Language Maintenance and Shift in Four Kaqchikel Towns. Ph.D. dissertation, Tulane University. New Orleans.

1998. Case Study Two: San Antonio Aguas Calientes and the Quinizilapa Valley. The Life of Our Language: Kaqchikel Maya Maintenance, Shift, and Revitalization, eds. R. Garzon et al., pp. 101-28. Austin.

Bruner, E. M., and B. Kirshenblatt-Gimblett. 1994. Maasai on the Lawn: Tourist Realism in East Africa. Cultural Anthropology 9:435-70.

n.d. Mayers' Ranch and the Kedong Maasai Manyatta. Draft, 1986.

Castañeda, Q. 1996. In the Museum of Maya Culture: Touring Chichén Itzá. Minneapolis.

Deitch, L. 1989. The Impact of Tourism on the Arts and Crafts of the Indians of the Southwestern United States. Hosts and Guests: The Anthropology of Tourism, ed. V. L. Smith, pp. 223-36. Philadelphia.

Ehlers, T. 1990. Silent Looms: Women and Production in a Guatemalan Town. Boulder.

1993. Belts, Business, and Bloomingdale's: An Alternative Model for Guatemalan Artisan Development. Crafts in the World Market: The Impact of Global Exchange on Middle American Artisans, ed. J. Nash, pp. 181-99. Albany.

Errington, F., and D. Gewertz. 1989. Tourism and Anthropology in a Post-Modern World. Oceania 60:37-54.

Foster, G. 1988 (1967). Tzintzuntzan: Mexican Peasants in a Changing World. Prospect Heights.

Fusco, C. 1995. The Other History of Intercultural Performance. English Is Broken Here: Notes on Cultural Fusion in the Americas, pp. 37-64. New York.

Garcia Canclini, N. 1993. Transforming Modernity: Popular Culture in Mexico, transl. L. Lozano. Austin.

1995. Hybrid Cultures: Strategies for Entering and Leaving Modernity, transl. C. Chiappari and S. López. Minneapolis.

Garrard-Burnett, V. 1998. Protestantism in Guatemala: Living in the New Jerusalem. Austin.

Karp, I., and S. D. Lavine. 1991. Exhibiting Cultures: The Poetics and Politics of Museum Display. Washington DC.

Kearney, M. 1995. The Local and the Global: The Anthropology of Globalization and Transnationalism. Annual Review of Anthropology 24:547-65.

Kirshenblatt-Gimblett, B. 1998. Destination Culture: Tourism, Museums, and Heritage. Berkeley.

MacCannell, D. 1976. The Tourist: A New Theory of the Leisure Class. New York. 
1992. Empty Meeting Grounds: The Tourist Papers. London.

Mitchell, T. 1991. Colonising Egypt. Berkeley.

Morley, D., and K. Robins. 1995. Spaces of Identity: Global Media, Electronic Landscapes and Cultural Boundaries. London.

Nash, J. (ed.) 1993a. Crafts in the World Market: The Impact of Global Exchange on Middle American Artisans. Albany.

1993b. Maya Household Production in the World Market: The Potters of Amatenango del Valle, Chiapas, Mexico. Crafts in the World Market: The Impact of Global Exchange on Middle American Artisans, ed. J. Nash, pp. 127-54. Albany.

Picard, M. 1995. Cultural Heritage and Tourist Capital: Cultural Tourism in Bali. International Tourism: Identity and Change, eds. M. Lanfant, J. Allcock, and E. Bruner, pp. 44-66. London.

Rodríguez Rouanet, F. 1996. Diccionario municipal de Guatemala. Guatemala City.

Rubio, J. A. 1938. Album de Guatemala. Guatemala City.

Sandstrom, A. R. 1991. Corn Is Our Blood: Culture and Ethnic Identity in a Contemporary Aztec Indian Village. Norman OK.

Stephen, L. 1991. Zapotec Women. Austin.

Stoll, D. 1982. Fishers of Men or Founders of Empire? The Wycliffe Bible Translators in Latin America. London.

Tice, K. E. 1995. Kuna Crafts, Gender, and the Global Economy. Austin.

Urry, J. 1990. The Tourist Gaze: Leisure and Travel in Contemporary Societies. London.

Watanabe, J. 1990. Enduring Yet Ineffable Community in the Western Periphery of Guatemala. Guatemalan Indians and the State: 1540-1988, ed. C. Smith. Austin.

Wilhite, M. 1977. First Language Acquisition: Textile Design Terminology in Cakchikel (Mayan).

$\mathrm{Ph}$. D. dissertation, Washington University. Seattle.

Wilson, R. 1995. Maya Resurgence in Guatemala: Q'eqchi' Experiences. Norman OK. 